\title{
Study of risk taking behaviors and practices long route drivers in Dharan Municipality of Eastern Nepal
}

\author{
S Uprety ${ }^{1}$, A Ghimire $^{1}$, M Poudel $^{2}$, DD Baral ${ }^{1}$ \\ School of Public Health and Community Medicine ${ }^{1}$, BPKIHS, Department of General Practices and \\ Emergency Medicine ${ }^{2}$ \\ B.P. Koirala Institute of Health Sciences, Dharan, Nepal
}

\begin{abstract}
Background: Due to its perception as a disease of development, road traffic accident and related injuries tend to be under recognized as a major health problem in developing countries. However, majority of the world's fatalities on the roads occur in low income and middle income countries. Since the main cause of road traffic accident is attributed to human risky behaviors, it is important to identify significant factors for risky behaviors of drivers. Objective: To know the risk taking behavior among drivers and practices of driving. Methods: This population based cross-sectional study. The study was conducted in Dharan, a township in Eastern Nepal. The study population includes of all long route drivers who are registered in membership of vehicle organization. Modified semi structured questionnaire was used for data collection. SPSS version 11.5 computer software was used for data entry and analysis. Results: Majority of study population belong to 25-29 years group. Majority of the drivers had valid license (98\%) and about $68.9 \%$ drivers didn't had any formal driving training school prior starting driving vehicle Most of them drive in high speed at highways but majority ignored that they take alcohol while driving. with growing age, years of driving had correlation of accidents among drivers population Conclusion: Study population comprises of youth drivers and most they had valid lenience. With the growing age drivers are neglecting traffic rules and sings and young driver are driving vehicles with overconfidently
\end{abstract}

Keywords: Alcohol, Dharan, road accident, risk behavior.

\footnotetext{
Address for correspondence Dr. Samyog Uprety Associate Professor School of Public Health and Community Medicine B P Koirala Institute of Health Sciences, Dharan Email: samyoguprety@gmail.com
} 


\section{Introduction}

The human factors commonly contribute to accident involvement in traffic ${ }^{1}$. A study of 2041 traffic accidents ${ }^{2}$ showed that human factors were contributing $95 \%$ of the accidents. In particular, driving behavior was identified as the most central of these factors. Consequently, a variety of studies have been carried out in order to identify variables which may influence accident involvement and risktaking behavior in traffic, meaning behavior that indicate the possibility of a negative health outcome for the individual as well as for others. Within psychology, the different perspectives of cognitive, personality and social psychology have all attempted to explain individual differences in risk-taking and traffic accident involvement ${ }^{3,4}$. Different studies have shown that risky driving behavior plays a major role in the occurrence of road traffic accident $5,6,7,8,9,10,11$.

According to the Government of $\mathrm{Nepal}^{12}$, nepal road sector assessment study 2013 reports expressed that registration of vechiles in Nepal has incresaed by 65\% sinces 2008 to 1.2 million in 2011 ,giving the density of 38 motor vechiles per 1000 people.An analysis of accidents showed that the numbers of road accidents and related fatality is very high in Nepal,with over 1,700 death 2009-10.The majority of fatalities occur outside Kathmandu vally and involved truks and busses, with many fatalities beigh pedestrians. These accidents is caused by risky taking behaviours of the drivers.

Carelessness on the part of the drivers is a major cause of accidents. Buses and microbuses plying on the narrow roads can be seen carrying passengers exceeding their capacities. Especially drivers who drives long route are venerable to have accidents due to their risky behavior, such as speeding, drunk driving and failure to fasten seat belts. There are limited studies on the risky behavior amongst driver in context of Nepal

\section{Methods}

This is cross-sectional study, conducted in Dharan, a township in Eastern Nepal. The study population includes of all long route drivers who are registered in membership of vehicle organization i.e. Vehicle Sang or Vehicles organization and used to drive bus, truck, van. Local distances car taxis are not included for the study. For the study Purpose, the long route drivers define as "the Drivers who drives more than $250 \mathrm{KM}$ per day". According to the vehicle sang and organization there are 300 drivers (Approx.) registered in their organization who are currently driving long rout. The total sample size is estimated as 300 long route drivers who are currently working in the field. Semi structural questionnaire used as tools for data collection.. For the asses the valid lenience, driver was asked to show their license paper. 
Inform written consent was taken from all the study subjects. Confidentiality was maintained. The data was entered in Microsoft Excel and analyzed by using SPSS version 11.5 and application of the test of significance, student $t$ test for numerical data to see the association between variables was applied.

\section{Results}

The sample sizes were 300 long route vehicle drivers but only 280 were interview 20 denied to participate, with $90 \%$ response rate.

Table 1: Scio-demographic profile of study population ( $\mathrm{N}=\mathbf{2 8 0}$ )

\begin{tabular}{|c|c|c|}
\hline Characteristics & Frequency & Percentage \\
\hline \multicolumn{3}{|l|}{ 1. Age } \\
\hline $20-24$ yrs. & 12 & 4.3 \\
\hline $25-29$ yrs. & 92 & 32.9 \\
\hline $30-34$ yrs. & 75 & 26.8 \\
\hline $35-39$ yrs. & 44 & 15.7 \\
\hline $40-44$ yrs. & 28 & 10.0 \\
\hline 45 and above & 29 & 10.4 \\
\hline \multicolumn{3}{|l|}{ 2. Religion } \\
\hline Hindu & 195 & 69.6 \\
\hline Kirat & 51 & 18.2 \\
\hline Buddish & 20 & 7.1 \\
\hline Others & 14 & 5.0 \\
\hline \multicolumn{3}{|l|}{ 3. Ethnicity } \\
\hline Brahmin & 45 & 16.1 \\
\hline Chhetri & 50 & 17.9 \\
\hline Dalit & 41 & 14.6 \\
\hline Hill Janjati & 122 & 43.6 \\
\hline Terai Caste & 22 & 7.9 \\
\hline \multicolumn{3}{|l|}{ 4. Literacy status } \\
\hline Illiterate & 28 & 10.0 \\
\hline Primary Level & 117 & 41.8 \\
\hline Secondary Level & 84 & 30.0 \\
\hline Higher secondary and above & 51 & 18.2 \\
\hline
\end{tabular}




\begin{tabular}{|l|l|l|}
\hline 5. Place of residence & 205 & 73.2 \\
Sunsari & 37 & 13.2 \\
Morang & 13 & 4.6 \\
Jhapa & 7 & 2.5 \\
Dhankuta & 18 & 6.4 \\
Others & & \\
\hline 6. Geographical area & 264 & 94.3 \\
Terai & 16 & 5.7 \\
Hill & & \\
\hline 7. Years of driving Experiences & 259 & 92.5 \\
Less than 20 years & 21 & 7.5 \\
Above 20 years & 30 & \\
\hline 8. Age of Driving stated & 151 & 10.7 \\
16-19 yrs & 68 & 53.9 \\
20-24 yrs & 26 & 24.3 \\
25-29 yrs & 5 & 9.3 \\
30-34 yrs & & 1.8 \\
35 and above yrs & 120 & 42.9 \\
\hline 9. Types of Vehicles & 73 & 26.1 \\
Bus & 26 & 9.3 \\
Van & 61 & 21.8 \\
Jeep & & \\
Truck & & \\
\hline
\end{tabular}

Table 1 shows socio-demographic profile of study population, majority of study population were belongs to 25-29 years group follow by 30-34 years with mean age 33.55 years (SD \pm 7.86$)$, most of them were Hindu (69.6\%) and Kirat $(18.2 \%)$ by religion. By ethnicity majority were Hill Janjati (Rai, limbu, Gurung, Magar) $43.6 \%$. Majority were literate (90\%) most of them were literate up to secondary level but only $10 \%$ were illiterate. Majority dwelling is in Sunsari districts $(73.2 \%)$ in Terai region. According to their driving experiences, most of them had less than 20 years driving experiences, drive bus. Drivers started their driving at age of 20-24 years $(53.9 \%)$ with mean age 23.86years, $S D \pm 4.25$ 
Table 2: Knowledge about driving of study population $(\mathrm{n}=280)$

\begin{tabular}{|c|c|c|}
\hline Characteristics & Frequency & Percentage \\
\hline \multicolumn{3}{|l|}{ 1. Do you know speed limit in urban area } \\
\hline Yes & 197 & 70.4 \\
\hline No & 83 & 29.6 \\
\hline \multicolumn{3}{|c|}{$\begin{array}{l}\text { 2. Who should carry the injured people from accident site to } \\
\text { nearby hospitals }\end{array}$} \\
\hline Same vehicles (if possible) & 196 & 70.0 \\
\hline Next immediate passing vehicles & 46 & 16.4 \\
\hline Ambulance & 28 & 10.0 \\
\hline Police van & 10 & 3.6 \\
\hline \multicolumn{3}{|c|}{$\begin{array}{l}\text { 3. Who should provide first-aid on the accident spot } \\
\text { Driver }\end{array}$} \\
\hline Police & 231 & 82.5 \\
\hline Public & 22 & 7.9 \\
\hline & 27 & 9.6 \\
\hline \multicolumn{3}{|l|}{ 4. Do you heard about traffic park } \\
\hline Yes & 178 & 63.6 \\
\hline No & 102 & 36.4 \\
\hline
\end{tabular}

Only few of them had good knowledge about traffics rules and signs, $70.4 \%$ had knowledge about the speed limit in urban area .About $70 \%$ respondents expressed that same vehicle should carry injured people from the accident site to the nearby hospitals and In vehicle there should basic first kits and basis aid (bandage, cotton) should provide by drivers at spot of the accident. About 36.4\% of respondent never heard about traffic park. 
Table 3: Attitudes towards driving of study population $(\mathbf{n}=280)$

\begin{tabular}{|l|c|c|}
\hline \multicolumn{1}{|c|}{ Characteristics } & Frequency & Percentage \\
\hline 1. Do you have valid license & 275 & 98.2 \\
Yes & 5 & 1.8 \\
No & & \\
\hline 2. Did you have formal driving training in driving school & 87 & 31.1 \\
Yes & 193 & 68.9 \\
No & & \\
\hline 3. Did you have formal test for driving at the time of receiving & 110 & 39.3 \\
license & 170 & 60.7 \\
Only driving & & \\
Both (written \& driving) & 161 & 57.5 \\
\hline Do you have proper medical test & 119 & 42.5 \\
Yes & & \\
No & & \\
\hline
\end{tabular}

Majority had valid license (98\%) and about 68.9\% drivers didn't had any formal driving training school prior starting driving vehicle (Table 3). During the receiving license, most of them (60.7\%) had both (Written \&driving) exam only few (57.5\%) had only driving exam. And only some $(42.5 \%)$ had proper medical test while receiving license. When asked stopping vehicle if you find accident, most of them (53.2\%) expressed that they will not stop at the accident site.

Table 4: Risk taking behaviors among respondents $(\mathrm{N}=\mathbf{2 8 0})$

\begin{tabular}{|l|l|l|l|l|}
\hline \multicolumn{1}{|c|}{ Characteristics } & \multicolumn{2}{c|}{ Sometimes } & \multicolumn{2}{c|}{ Never } \\
\hline & Frequency & \multicolumn{1}{c|}{$\%$} & Frequency & $\%$ \\
\hline Overtake any vehicles at turning & 266 & 95 & 14 & 5 \\
\hline Park at wrong side & 89 & 31.8 & 191 & 68.2 \\
\hline Drive at high speed & 175 & 62.5 & 105 & 37.5 \\
\hline Drive after alcohol & 15 & 5.4 & 265 & 94.6 \\
\hline Drive with women sitting beside you & 236 & 84.3 & 44 & 15.7 \\
\hline Have sexual relation with women on a long route & 6 & 2.1 & 274 & 97.8 \\
\hline
\end{tabular}


When asked about the driving practices, about $95 \%$ of them frequently overtake the vehicles at turning and $68.2 \%$ parks at wrong side of the road. Most of them drive in high speed at highways but majority ignored that they take any alcohol while driving and have sexual relation with women on a long route and expressed that sometimes drive with women sitting beside them ( table 4). Majority of driver expressed that, driving with intake of alcohol and drugs, driving vehicles with carelessly and over confidently were the most reasons from drivers' fault to occur accidents.

Table 5: Opinions of drivers towards causes of accidents due to drivers fault

\begin{tabular}{|l|l|l|}
\hline \multicolumn{1}{|c|}{ Characteristics } & Frequency & \multicolumn{1}{|c|}{ Percentage $^{*}$} \\
\hline Driving with intake of alcohol and drugs & 162 & 57.9 \\
\hline Driving vehicles carelessly and over confidently & 159 & 56.8 \\
\hline Driving in high speed & 90 & 32.1 \\
\hline Overtaking the vehicles in high speed & 65 & 23.2 \\
\hline Bad condition of vehicles & 40 & 14.3 \\
\hline Overloading passengers \& load and parking wrong side & 39 & 13.9 \\
\hline Driving wrong side of the road & 37 & 13.2 \\
\hline
\end{tabular}

*\% $\neq 100$ because of multiple responses

When asked what are their opinion and suggestion about the prevention of accidents, most of them suggested that, when driving vehicles drive slowly and carefully, while driving don't take alcohol, update vehicles regularly .They also expressed utilization of traffic police in heavy traffic places will somehow prevent of major heavy traffic problems.

Table 6: Suggestions on preventions and control of accidents according to respondents*

\begin{tabular}{|l|l|l|}
\hline \multicolumn{1}{|c|}{ Characteristics } & \multicolumn{1}{|c|}{ Frequency $^{\mid}$Percentage $^{\star}$} \\
\hline Drive slowly and carefully & 201 & 71.8 \\
\hline Use zebra-crossing for crossing roads & 171 & 61.1 \\
\hline Don't take alcohol while driving and drugs & 121 & 43.2 \\
\hline Don't stop vehicle frequently in the road & 143 & 51.1 \\
\hline Avoid domestics animals in the road & 110 & 39.3 \\
\hline
\end{tabular}




\begin{tabular}{|l|l|l|}
\hline Be careful while overtaking & 79 & 28.2 \\
\hline Update your vehicles regularly & 63 & 22.5 \\
\hline Always follow traffic signals while driving & 52 & 18.6 \\
\hline Drive vehicles after proper driving training center & 52 & 18.6 \\
\hline
\end{tabular}

Majority of the drivers complain that pedestrian didn't use zebra crossing, so they suggest that use zebra-crossing for crossing roads and avoid domestics animals away from the road, not only drivers but pedestrian also follow the traffic rules. While crossing the road carefully check the vehicle in the road and cross the road, which were the major suggestion given by drivers to prevent accident by pedestrian side.

Table 7: Mean of Outcome variables accident done in life time of driving

\begin{tabular}{|l|l|l|l|l|}
\hline \multirow{2}{*}{ Characteristics } & \multicolumn{2}{c|}{ Accident done } & \multirow{2}{*}{ Test value } & \multirow{2}{*}{ P value } \\
\cline { 2 - 4 } & \multicolumn{1}{|c|}{ Yes } & \multicolumn{1}{|c|}{ No } & \\
\hline Age & $34.92 \pm 8.483$ & $32.66 \pm 7.331$ & 2.162 & 0.031 \\
\hline Years of driving & $11.15 \pm 8.124$ & $8.74 \pm 6.41$ & 1.262 & 0.208 \\
\hline Age at Driving started & $23.76 \pm 4.1$ & $23.93 \pm 4.358$ & 0.368 & 0.713 \\
\hline
\end{tabular}

Average age of the respondents was found significantly higher among who had met accidents. The average years of driving was higher among people who had met accident but not significant. The mean age of starting driving was not significant in accident status (Table 7).

\section{Discussion}

The objective of the study was to know the risk taking behavior among long route drivers and practices of driving among the drivers of Dharan municipality.

\section{References}

1. Grayson G.B, Maycock, G., 1988. From proneness to liability. In: Rothengatter, J.A and DBruin, R., Editors, 1988. Road User Behaviour. Theory and Research, Van Gorcum, Assen, pp. 234-242.

2. Sabey B.E., Taylor, H. 1980. The known risks we run: the highway (Transport and Road Research Laboratory Supplementary Report 567). Crow throne, TRRL, UK.

3. Arthur W.A., Barrett, G.V. and Alexander, R.A. Prediction of vehicular 
accident involvement: a Meta analysis. Human Performance.1991; 4: 89-105.

4. Parker, D., Manstead, A.S.R. and Straddling, S. Extending the theory of planned behaviour: the role of personal norm. British Journal of Social Psychology. 1995; 34:127-137

5. Evans L. The dominant role of driver behavior in traffic safety. Am J Public Health 1996; 86:784-6.

6. Parker D, Reason JT, Manstead ASR, et al. Driving errors, driving violations and accident involvement. Ergonomics 1995; 38:1036-48.

7. Parker D, West R, Manstead ASR, et al. Behavioral characteristics and road traffic accident involvement. Accid Anal Prev 1995; 27:571-81.
8. Evans L. A new traffic safety vision for the United States. Am J Public Health 2003; 93:1384-6.

9. Stradling $\mathrm{S}$. Drivers who speed. Impact 2000; 9:38-41.

10. MC, Lyman Da, Baruya A. The effect of drivers' speed on the frequency of road accidents. TRL Report 421. Crow thorne: TRL Limited, 2000.

11. Redelmeier DA, Tibshirani RJ, Evans L. Traffic-law enforcement and risk of death from motor-vehicle crashes: case-crossover study. Lancet 2003;361:2177-82

12. Government of Nepal, The world bank . Nepal road sector assessment study. May $30^{\text {th }} 2013$. 